\title{
The "Road Map" of the Potential Development Assessment of the Component Machine Building in the Single-Industry Region
}

\author{
Svetlana Kazachenko ${ }^{1 *}$, Svetlana Kulay ${ }^{1}$, Evgeniy Pudov ${ }^{1}$, Evgeniy Shvakov ${ }^{2}$ \\ ${ }^{1}$ T. F. Gorbachev Kuzbass State Technical University, Russia, 653039, Kemerovo Region, \\ Prokopyevsk, st. Nogradskaya, 19a \\ ${ }^{2}$ Altai state university, 656049, Altai Krai, Russia, Barnaul, Lenin Ave., 61a
}

\begin{abstract}
The development of component machine building in mining regions can become a key factor in the economic diversification, as well as the implementation of the import substitution program in Russia. The aim of this study is to develop an action plan ("road map"). It is also to assess the possibility of developing component machine-building in the singleindustry mining region (on the example of Kemerovo region). The objectives of the study include formulation of goals and objectives of the "road map". The task is also to identify the key elements and main directions of the component machine-building development, to form the action plan taking into account the time factor. The results of the road map provide an information base for the initial stage of the component machine building development program. The production capabilities of the region, domestic demand for components and assemblies of the working equipment, personnel needs, and opportunities for placing innovative business as a resident of TOSER in single-industry town, all these should be taken into account.
\end{abstract}

\section{Introduction}

The vital task of the present development of any single-industry region is the formation of such technological chains in it that it would allow to diversify its economy. It is also the task of reducing its import dependence. At the same time it is the task of the increasing the level of regional localization of value added. These fields are identified as priorities at the strategic planning level of socio-economic, scientific, technological and innovative development of the region and the country as a whole.

The high share of imported means of production makes a problem. It leads to the region poor involvement in global value added chains. Therefore, one of the most effective tools for the implementation of the above tasks is the creation of component machine building regional centers. Their activities aim to build a crosscutting industrial structure in the region through the construction of new enterprises and modernization of the existing ones. Such centers should be coordinated at the regional level.

\footnotetext{
*Corresponding author: pfkuzstu_onir@mail.ru
} 
However, the analysis of the regulatory framework showed the lack of the existing comprehensive policy documents, which requires a comprehensive action plan ("road map"). Their priorities are to assess the development of component machine building in the region.

\section{Materials and Methods}

The study used the following methods: analysis of the regulatory framework at the regional and Federal level; analysis of the main trends in the development of the coal industry and mining engineering; structural analysis of economic relations of the regional industrial enterprises; statistical observation; analysis and synthesis; system and program approaches.

\section{Results and Discussions}

The main directions of the plan to assess the potential of component machine building development in the single-industry region should include the following elements.

I. Component localization - definition of major consumer products of the component machine building.

A component localization can become one of the directions to implement the import substitution programs realizing it in the industry of the Russian Federation and also diversify the economy of the single-industry region $[14,15]$. Considering a high share of foreign equipment of the regional enterprises, it is necessary to arrange the production of the main knots and units of machines and the equipment inside the region. The stages of opportunities evaluations of the component machine building development in the region are the following:

Stage 1 includes collection of information about the working equipment at the regional industrial enterprises, in particular, quantity of equipment pieces (by types); manufacturer's data and initial cost of the equipment; cost put into operation and redundant machinery (for the last 5 years); operating time of the equipment, its actual productivity; the main knots and the replaceable components; service data (firm, terms, cost).

Stage 2 includes processing and the analysis of information:

- analysis of equipment usage (level of loading, technical readiness);

- analysis of operating time of the equipment;

- analysis of the movement and structure of fixed assets (active);

- analysis of composition and structure of components;

- assessment of efficiency between companies interactions.

Stage 3 includes making conclusions and results: making the list of the foreign production machinery operating in the region (in branches); creating the database of nodes and aggregates in a section of component machine building production; determining a part of the production chain creating demand for the component machine building products that forms a base to assess the possibility of the implementation of the open technological way in the region.

II. Production capacity means the evaluation of existing production capacity in order to identify potential manufacturers of component machine building products.

Increase in a share of import substitution in the regional machine-building industry requires existence of powerful and wide production capabilities. According to that, firstly it is necessary to estimate the possibilities of the operating machine-building enterprises in order to identify the reserves of production capacities. It will let determine the level of potential charge of the operating machine-building enterprises, making innovative production [1-5]. Thus, it will be possible at the regional level to create a transparent 
technological way, or so called a value added chain that influences on the indicators of economic development of the region positively. This complex of actions can be realized at three stages.

The first stage includes collecting the information of machine-building enterprises activity for the last 5 years. It is about produced goods, basic technical and economic indicators, including the information about production capacities, about product sales (according to buyers), about deliveries of material resources (according to suppliers).

The second stage is a processing and the analysis of collected information, including:

- analysis of loading capacities level, identification of production reserves;

- analysis of dynamics and structure of realization;

- analysis of dynamics and structure of deliveries (supply);

- assessment of interactions efficiency.

At the final stage conclusions and results are being formed. The enumeration of free production capacities is being made. An assessment of opportunities of additional charge of the enterprises of the innovative production is being given. The part of a production chain connected with material formation and technical resources for primary branches of the regional industry is being monitored.

III. Growth centers mean an identification of favorable areas to accommodate potential new producers of component machine building product.

Another important task of import substitution development in the region is to define the centers of growth for new machine-building enterprises. $[6,7]$ First, it can be fulfilled in the single-industry towns in Kemerovo region, which need the economic diversification greatly [8-10]. Realization of this task also supposes several stages. They direct on the forming of the register of the territories with favorable business conditions.

At the initial stage it is necessary to develop a complex assessment technique of investment climate on the territories (taking the example of single-industry towns in Kemerovo region) for the new industrial enterprises. Detecting the indicators characterizing favorable conditions for business development will be carried out by expert's evaluations method. Representatives of three structures will become the experts: the authorities, science, business representatives. That will allow revealing favorable conditions for development of social, innovative and investment components of machine building in Kemerovo region. It will allow making the list of the most possible favorable conditions for innovative businesses in machine-building branch in Kemerovo region.

The developed technique will allow forming the rating of single-industry towns based on the level of the investment climate for innovative machine building in Kemerovo region, splitting them in clusters:

- a cluster No. 1 - single-industry towns with favorable investment climate;

- a cluster No. 2 - single-industry towns with investment potential;

- a cluster No. 3 - single-industry towns with neutral investment climate;

- a cluster No. 4 - single-industry towns with unfavorable investment climate.

At the same time, single-industry municipal units of the first and second clusters will become potential centers of growth for the new production placement.

IV. Personnel - determining the needs of enterprises in the workforce.

Human capital is an important factor in increasing the innovative activity of basic economic branches. Personnel training should be carried out taking into account the requirements of not only the operating industrial enterprises of the region, but also the new investment projects [11].

Firstly, it is necessary to collect the staff deficit data and the expected personnel needs for the region industrial enterprises in the directions of training, specialties, labor professions. That can be also because of additional jobs (including the connection with the investment projects implementation) or leaving of the employed population. It can happen 
according to the time that is short-term (1 year), medium-term (2-3 years) and long-term requirement (4-6 years). It depends on the education level (primary professional education, secondary professional education, the higher education, additional training, and retraining, professional development).

The results will include the formation of register requirements of the enterprises for personnel, including the existing enterprises and new investment projects of machine building in the region.

If we consider the pendulum existence of population migration and the developed transport infrastructure in the region, there will be the need of coordinated attention of the state and business structures to a question of the labor market regulation. It also includes training for the basic economic brunches of the region [12]. The leading scientists of the Russian Federation have noted a certain adaptation feature of the population during unemployment periods. It is so called labor mobility of the population in 12 single-industry towns of Kemerovo region. Increase in population labor mobility is one of possible adaptation models and the development of the single-industry towns [13].

As it has been mentioned, it is necessary to estimate the intensity and the directions of the population labor mobility in the single-industry towns of the region with the help of:

- the data collection of the personnel structure according to the residence of the regional industrial enterprises employees;

- the evaluation of the intensity level of pendulum population migration in the singleindustry towns of Kemerovo region;

- the definition of the directions of the population labor migration in the single-industry towns of the region.

The final stage will include the correlation of requirements of the industrial enterprises in personnel with demand directing in training. These indicators will be bounded to the territories of Kemerovo region. It will give the chance to reveal the directions of change in the training system for machine-building enterprises. It will also allow creating the training system for investment projects implementations of the regional machine building. The effective spatial distribution of the human capital across municipal units will be supposed to define according to the regional strategy of economic development.

Totally, the implementation of the four directions, taking into account the sequence of tasks within each of them, can be presented in the form of a road map (Fig. 1) 


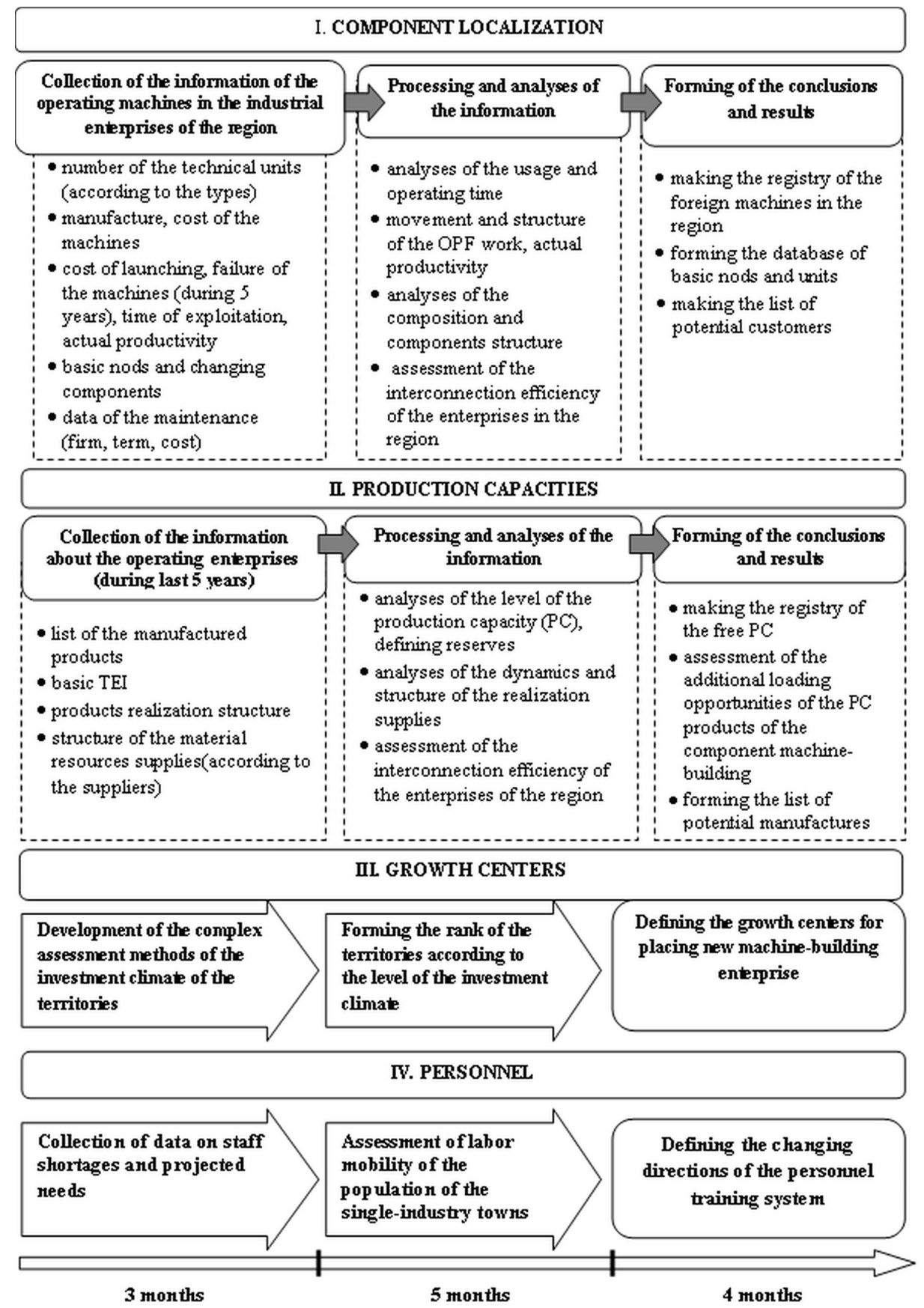

Fig. 1. The scheme of the "road map" assessment of the capacity development component of the machine-building in the single-industry region.

\section{Conclusion}


The study formed the plan of measures (road map) defining the capacity development component of the machine-building in the single-industry region (on the example of Kemerovo region), aimed at:

1) identifying the reserves of production capabilities of existing machine-building enterprises;

2) making the list of territories with favorable business conditions;

3) making the list of personnel needs of the enterprises in Kemerovo region;

4) making the list of foreign equipment working in the region divided by the branch principle;

5) creating the database of units and assemblies of existing equipment in the component machine-building products context.

Thus, the information base will be formed. It will be the starting point for the further development of component machine-building. It will have a positive impact on the economy of the region from different sides.

As a part of import substitution, this will reduce the dependence of business entities on foreign markets. On the other hand, the opportunity of diversification of the regional economy will appear, i.e., reduction of single-industry dependence. It will let develop the territory and create an ultimate technological system. Thereby it will increase the level of localization of value added at the regional level.

The regional authorities and the local government can use the received results of the actions implementation. They can use them for developing and specifying the strategic and territorial planning documents. It also includes the concept and forms of regional personnel policy applying to the single-industry towns. Results of the research can be also used by businesses for the assessment of the potential and investment risks into the single-industry towns. It will be useful in order to make reasonable the efficiency of the machine-building innovative projects and apply it in forming personnel policy at the industrial enterprises of the region.

\section{References}

1. P.M. Buston, S. Balshine, Behav. Processes, 76:2, 152 (2007)

2. P. Annoni, K. Kozovska, Econometrics and Applied Statistics Unit (London, BHHT, 2010)

3. M. Bussiure, J. Imbs, R. Kollmann, R. Rancire, Amer. Econ. J.: Macroec., 5, 75 (2013)

4. L. A. Kormishkina, E. D. Kormishkin, N. N. Semenova, D. A. Koloskov Mediter. J. Soci. Sci. 6:4, 163 (2015)

5. G. S. Merzlikina, Manažment Podnikov 1:4, 56 (2016)

6. T. R. Casey, S. Ruutu, 24th Annual RESER Conference, Helsinki, Finland, 225 (2014)

7. M. Kautonen, R. Pugh , M. Raunio $24^{\text {th }}$ Annual RESER Conference, Helsinki, Finland, 724 (2014)

8. D. Carson, D. Carson, Scand. J. Hosp. \& Tour., 14, 460 (2014)

9. D. Littlewood, J. Bus. Eth., 120, 39 (2014)

10. O. Dinius, A. Vergara Company Towns in the Americas: Landscape, Power, and Working-Class Communities (UGA Press, Athens-Clarke County, 2011)

11. E. V. Poyarkova, A. I. Serdyuk, A. D. Pripadchev, The Strategies of Modern Science Development: Proceedings of the VIII International scientific-practical conference North Charleston, SC, USA, 60 (2015)

12. S. Kulay, G. Kayachev, E3S Web of Conferences, 21, 04029 (2017) 
13. M. Porter, FEDQ, 14:1, 15 (2000)

14. E. Budny, M. Chłosta, W. Gutkowski, Proceedings of the18th ISARC Conference, Krakow, Poland, 1 (2001)

15. A. A. Khoreshok, E. Yu. Pudov, O. V. Lyubimov, Materials of the Chinese-Russian forum "Safe Production, Mines and Technological Equipment", 36 (2009) 